\title{
Disnea tras episodio de emesis
}

\author{
Molero Silvero, E. ${ }^{1}$, Bartolomé Cela, E. ${ }^{2}$, Gijón Gallego, F. ${ }^{3}$, García de la Llana, M. A. ${ }^{4}$
}

Sanid. mil. 2015; 71 (3): 201-202; ISSN: 1887-8571

\section{PRESENTACIÓN}

Mujer de 55 años de edad con antecedentes personales de retraso psicomotor perinatal remitida de otro centro hospitalario por cuadro de disnea aguda grave. La paciente estaba siendo estudiada por cuadro de vómitos incoercibles postprandiales de aproximadamente un mes de evolución. Durante la realización de las pruebas para estudio del cuadro, presenta episodio de emesis y brusco deterioro clínico.
A su ingreso, la paciente presenta intensa taquipnea, SatO2 90-91\%, y gasometría arterial: 7.32/65/57/33/5.6 con mascarilla-reservorio. Se procede a intubación orotraqueal y conexión a ventilación mecánica, iniciándose soporte inotropo vasoactivo por inestabilidad hemodinámica, ingresando en UCI.

Se realiza radiografía torácica (Fig. 1) y a continuación TC torácico (Fig 2) que se exponen.

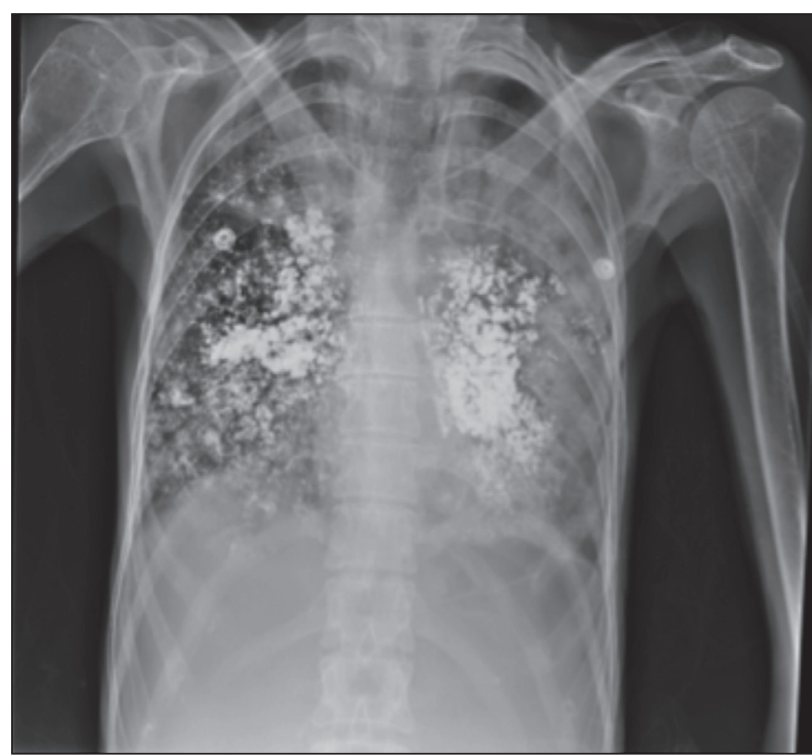

Figura 1. Radiografía AP en decúbito supino realizada con portátil.

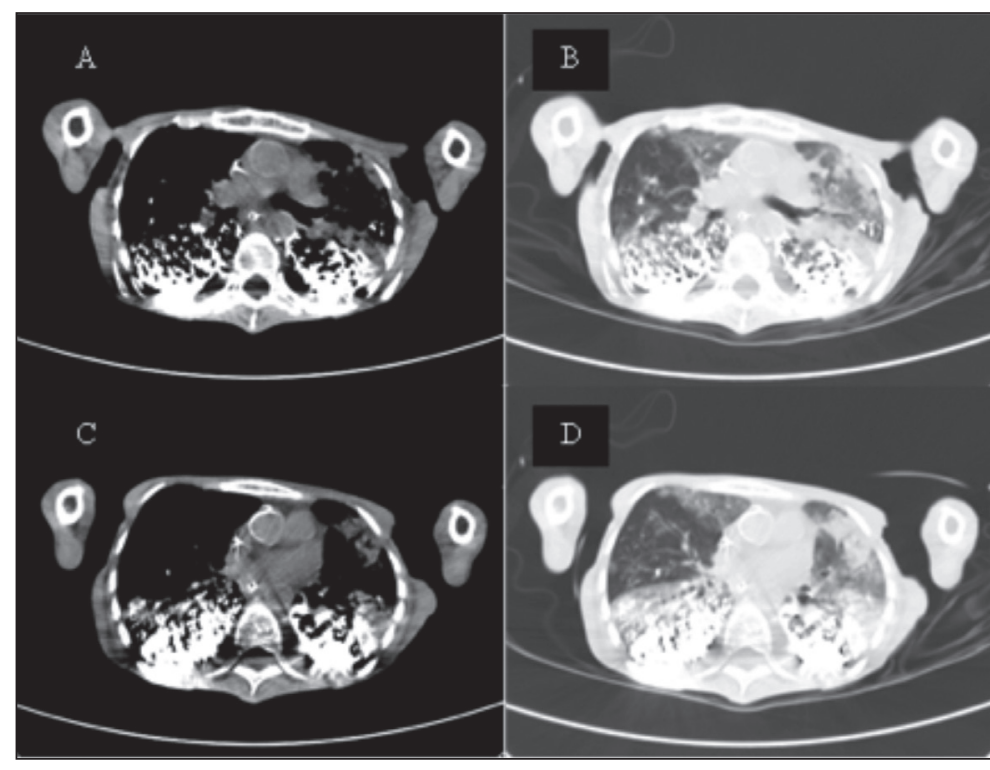

Figura 2. Distintos cortes de Tomografía Axial Computarizada de tórax. Imágenes $A$ y $C$, ventana de mediastino. Imágenes $B$ y $D$, ventana de pulmón.

\footnotetext{
${ }^{1}$ MIR $5^{\circ}$ año.

2 Tcol Médico.

${ }^{3}$ Médico civil.

${ }^{4}$ Cor. Médico.

Servicio de Medicina Intensiva. Hospital Central de la Defensa Gómez Ulla. Madrid.

España.
}

Dirección para correspondencia: Esperanza Molero Silvero. Servicio de Medicina Intensiva. Hospital Central de la Defensa Gómez Ulla. Glorieta del Ejército, 1. 28047 Madrid. España. espe_molero@yahoo.es 


\section{Diagnóstico: Aspiración de contraste de bario}

La radiografía torácica (Fig. 1) muestra material de contraste de alta densidad distribuido de forma bilateral.

El TC torácico (Fig 2) evidencia ocupación alveolar, predominantemente en lóbulos inferiores y planos posteriores, aunque también en lóbulos superiores con patrón condensativo y vidrio deslustrado, dejando libre únicamente el lóbulo medio.

\section{DISCUSIÓN}

La aspiración de contenido gástrico es una entidad que suele presentarse en pacientes con bajo nivel de conciencia, patología psiquiátrica, alteraciones neuromusculares y ancianos con alta comorbilidad, sobre todo en alteraciones de la morfología/actividad del tubo digestivo. La incidencia de la aspiración de contraste baritado varía según las series, aunque la mayoría coincide en su excepcionalidad. Fung et al contabiliza hasta un $8 \%{ }^{1}$. Las complicaciones derivadas dependen tanto de la cantidad y densidad de la solución, como de la distribución dentro del árbol respiratorio, de la aspiración concomitante de contenido gástri$\mathrm{co}^{2}$ y la patología de base del paciente, pudiendo ser una entidad asintomática o llegando a desarrollar un distress respiratorio agudo e incluso el fallecimiento del paciente ${ }^{3,4}$. La tasa global de mortalidad en aspiración masiva puede ascender al 30\% y hasta un 50-60\% si aparece shock o síndrome de distress respiratorio del adulto $^{3}$. En la actualidad, la fibrobroncoscopia se emplea en casos de hipoxemia severa y/o refractaria (por efecto shunt) para aspiración de la mayor cantidad posible de material, así como para obtención de muestras para realizar cultivo microbiológi$\mathrm{co}^{3,5}$. El lavado bronquioalveolar no está avalado por la posibilidad de diseminación del material ${ }^{5}$. Dentro del manejo terapéutico, se recomienda la antibioterapia de amplio espectro por la elevada posibilidad de sobreinfección bacteriana y el drenaje postural y la cinesiterapia para facilitar la expulsión del aparato respiratorio ${ }^{3}$.

\section{BIBLIOGRAFÍA}

1. Fung KP et al. Investigation and outcome of 121 infants and children requiring Nissen fundoplication for the management of gastroesophageal reflux. Clin. Invest. Med. 1990;13:237-246.

2. Whiting, J. Aspiration of Barium. N Engl J Med 2003; 348:2582-2583.

3. Severe barium sulphate aspiration: a report of two cases and review of the literature. Signa Vitae 2007;2(1):25-28.

4. Fuentes Santos, C.; Steen, B. Aspiration of Barium Contrast. Case Rep Pulmonol. 2014; 2014: 215832.

5. Martínez Martín, M.; Gil Martínez, P. Neumonitis aspirativa por contraste de bario en paciente mayor en estudio por disfagia progresiva. Rev Esp Geriatr Gerontol. 2010;45:173-4. - vol.45 núm 03. 